\title{
AVICENNA AND THE LIBER DE CAUSIS: A CONTRIBUTION TO THE DOSSIER
}

\author{
Cristina D'Ancona Costa* \\ Dipartimento di Filosofia. Università di Padora
}

\section{RESUMEN}

Partiendo del conocimiento que los árabes tuvieron de los textos neoplatónicos atribuidos a Aristóteles, tales como la Pseudo-Teología y el Liber de Causis, la autora de este estudio investiga el posible conocimiento que Avicena tuvo de este último libro, conocido en el mundo árabe por el título de Kaläm fĩ mahd al-hayr. Se apoya, para ello, en el análisis de cuatro pasajes de la Metafísica de la gran enciclopedia filosófica Al- ̌̌ ifá («La curación»).

Palabras clave: Avicena, neoplatonismo, Pseudo-Teología, Liber de Causis. Al-Šifā'.

\begin{abstract}
Taking as a starting point the knowledge that the Arab world had of the Neoplatonic texts ascribed to Aristotle, such as the Pseudo-Theology and the Liber de Causis, the author of this study investigates the possible knowledge that Avicenna had of this under book, well-known in the Arab world under the title of Kaläm fI mahd al-hayr. In order to demonstrate this, she provides an analysis of four passages that belong to the Metaphysics of the great philosophical encyclopaedia Al-Šifä' («The cure»).
\end{abstract}

Key words: Avicenna, Neoplatonism, pseudo-Theology, Liber de Causis, Al-Šifā'.

The Neoplatonic influence on Ibn Sinna's philosophical thought has been acknowledged time and again in many important areas of his work. His metaphysical and psychological doctrines, as well as his ideas about the ascension towards the First Principle and final union with it (ittisălwusuil), have been explored from the viewpoint of their relationship with the Neoplatonic sources.' The

* I am very grateful to Marc Geoffroy, CNRS-IRHT, Section Arabe, Paris and to Ahmed Hasnaoni, CNRS; SIHSPAI, Paris, for their remarks and corrections on a first draft of this article, as well as to Jules Janssens, De Wulf-Mansion Centrum, Leuven, and to Amos Bertolacci, Yale University, for having discussed it with me. For all its weaknesses and errors I obviously remain the sole responsible.

1 A.M. Goichon, La distinction de l'essence et de l'existence d'après Ibn Sīnä (Avicenne), Paris, Desclée de Brouwer, 1937, gives room only seldom to the Neoplatonic sources of Ibn Sinä's thought. The Neoplatonic influence has been acknowledged, albeit differently evaluated, by L. Gardet, La pensée religieuse d'Avicenne (Ibn Sinā), Paris, Vrin, 1951 (Études de Philosophie Médiévale, 41), passim; A.M. Goichon, «La philosophie de l'être», in IBLA, 57 (1952), pp. 49-61; J. Janssens, Avicenna: tussen neoplatonisme en islam, Ph.D. Leuven 1984 (I am very grateful to Jules Janssens for having allowed me to read a section of his dissertation: see below, note 38); Id., "Ibn Sinā's Ideas of ultimate realities: Neoplatonism and the Qur'ān as problem-solving paradigms in the Avicennian system», in Ultimate Reality and Meaning, 
attention of scholarship was obviously attracted mostly by the Notes Ibn Sīna wrote on the pseudoTheology of Aristotle, the main remaining part of the Arabic version of seventeen Plotinian treatises. Translated into Arabic within the circle of al-Kindi and adapted to the religious and cultural needs of the new-born falsafa, the Plotinian writings became an important part of the philosophical curriculum of those among the Arab intellectuals who were interested in foreign sciences. Even though we still do not possess a critical edition of the pseudo-Theology of Aristotle and related Plotinian Arabic texts, ${ }^{2}$ a series of research by Paul Kraus, ${ }^{3}$ Franz Rosenthal, ${ }^{4}$ Gerhard Endress ${ }^{5}$ and Friderich W. Zimmermann ${ }^{6}$ shed light on this text and reached the conclusion that it traces back to the so-called "Arabic Plotinus Source", namely, to a translation of selected treatises from Enneads IV-VI which was wider than the pseudo-Theology' itself, and whose remaining parts share in the same stylistic and doctrinal features. ${ }^{7}$ The Prologue to the pseudo-Theology informs us that it was

10 (1987), pp. 252-271; A.L. Ivry, «An evaluation of the Neoplatonic elements in al-Fārābī’s and Ibn Sīnā's metaphysics»,

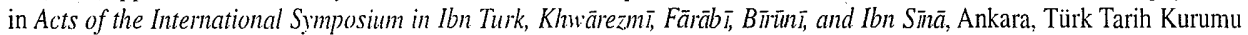
Basimevi, 1990, pp. 163-174; P. Morewedge, «The Neoplatonic structure of some Islamic mystical doctrines», in Neoplatonism and Islamic Thought ed. by P. Morewedge, SUNY Press, Albany, 1992, pp. 51-75 (Studies in Neoplatonism: Ancient and Modern, 5); M. Marmura, «Quiddity and universality in Avicenna», ibid., pp. 77-87; L. Westra, «Self-knowing in Plato, Plotinus and Avicenna», ibid., pp. 89-109. On the contrary, according to E. Booth, Aristotelian aporetic ontology in Islamic and Christian thinkers. Cambridge. Cambridge U.P., 1983, p. 109, «there is nothing Plotinian in [Ibn Sīnäs] alSifä' ontology». On Ibn Sinnä's psychology, see now the synthetic but really useful study by M. Sebti, Avicenne. L'âme humaine, Paris, P.U.F., 2000. M. Sebti takes into account the Plotinian inspiration of many aspects of the Avicennian doctrine of soul, its nature and operations.

2 The editio princeps of the pseudo-Theology of Aristotle was provided in 1882 by F. Dieterici, Die sogenannte Theologie des Aristoteles aus arabischen Handschriften zum ersten Mal herausgegeben von F. Dieterici. Leipzig, 1882 (repr. Amsterdam, Rodopi, 1965). The work was edited once again by 'A. Badawī, Aflutitin 'inda l-'Arab. Plotinus apud Arabes. Theologia Aristotelis et fragmenta quae supersunt, Cairo, Dār al-nahḍat al-'Arabíyya, 1955, 1966, Kuwait 1977 (Dirāsāt Islamīya, 20). For the status quaestionis on this text see M. Aouad, «La Théologie d'Aristote et autres textes du 'Plotinus Arabus'», in Dictionnaire des Philosophes Antiques publié sous la direction de R. Goulet, I, Paris, Éd. du CNRS, 1989, pp. 541-590.

3 P. Kraus, «Plotin chez les Arabes. Remarques sur un nouveau fragment de la paraphrase arabe des Ennéades», in Bulletin de l'Institut d'Egypte, 23 (1940-41), pp. 263-295.

4 F. Rosenthal, «Aš-Šayh al-Yūnānī and the Arabic Plotinus Source», in Orientalia, 21 (1952), pp. 461-492; 22 (1953), pp. 370-400; 23 (1954), pp. $42-65$ (repr. in Greek Philosophy in the Arab World. A Collection of essays. Greath Yarmouth, 1990).

5 G. Endress, Proclus Arabus. Zwanzig Abschnitte aus der Institutio Theologica in arabischer Übersetzung, Imprimerie Catholique, Wiesbaden-Beirut, 1973 (Beiruter Texte und Studien, 10).

6 F. W. Zimmermann, «The Origins of the so-called Theology of Aristotle», in Pseudo-Aristotle in the Middle Ages. The Theology and other texts, ed. by J. Kraye, W.F. Ryan and C.B. Schmitt, London, The Warburg Institute, 1986, pp. 110-240.

7 The pseudo-Theology of Aristotle is presented by G. Endress as «an extensive commentary-paraphrase of texts from the Enneads (books IV-VI) of Plotinus, transmitted and received as Aristotle's true 'Theology' (Utülüü̆iva wa-huwa qawl 'alā l-rubïbiyya) as commented by Porphyry, and translated by 'Abd-al-Masịn ibn Nā'ima from Hịms (the ancient Emesa). Other parts of the Arabic Plotinus source, homogeneous in terminology, style and interpretation with the 'Theology', and stemming from the same 'Plotinus source' of the Arabic ttradition, have been transmitted separately as dicta of the 'Greek master' (al-Šayhal-Yünānn ) and in an 'Epistle on Divine Knowledge' (Risäla fi l-'ilm al-ilähî). The 'Theology of Aristotle' and its corollaries are fundamental for al-Kindi's world-view in which he places his propaganda for rational research» (G. Endress, The Circle of al-Kindi. Early Arabic Translations from the Greek and the Rise of Islamic Philosophy, in The Ancient Tradition in Christian and Islamic Hellenism. Studies on the Transmission of Greek Philosophy and Sciences dedicated to H.J. Drossaart Lulofs on his ninetieth birthday, ed. by G. Endress and R. Kruk, Leiden 1997, pp. 43-76, the quotation, p. 53). 
meant to be read in continuity with Aristotle's Metaphysics and as providing an account of the suprasensible causes whose necessary existence was established by Aristotle himself: ${ }^{8}$ On the grounds of this Prologue and other texts produced within the circle of al-Kindi, ${ }^{9}$ Zimmermann maintained that the idea of an inner harmony between Aristotle's metaphysics and Plotinus' theology inspired both the production of the Arabic Neoplatonic texts and their attribution to Aristotle - a baffling fact indeed, which led many scholars in the past to conceive of the Arabic Neoplatonic texts as items of deliberate forgery. ${ }^{10}$ In Zimmermann's interpretation, on the contrary, the attribution of the Neoplatonic materials to Aristotle is but an effect of reading Aristotle's metaphysics within the Neoplatonic framework, an approach which is partly inherited from late Antiquity, and partly due to the intention to supplement Aristotle's own thought with a proper theological doctrine. ${ }^{11}$ This pattern evidently lies in the background of the repeated claim by al-Fārābī, in his treatise On the

8 «Now we have previously completed an explanation of them [i.e., the four Aristotelian causes al-hayilla, al-süra, al-'illa l-fä'ila, al-tāmm], and an account of their causes in our book which is after the Physics, and have arranged these causes in the divine intellectual arrangement, after the exposition of the soul and of nature and its action. (...) Now since we have completed the customary prefaces, which are principles that lead on to the explanation of what we wish to explain in this book of ours, let us not waste words over this branch of knowledge, since we have already given an account of it in the book of the Metaphysics, and let us confine ourselves to what we have presented there, and at once mention our aim in what we wish to expound in the present work, which is universal knowledge, composed in order to deliver ourselves of the sum of our philosophy and towards which we have directed the whole of what our books contain, so that the mention of the aims of it may induce the student to desire it, and may help him to understand it, in such of it as it as has gone before» (transl. Lewis): ed. Dieterici, p. 2.11-13 and 3.2-8; ed. Badawi. p. 5.1-3 and 5.10-6.2. Lewis' translation of the Arabic faces the Greek in Plotini Opera ediderunt P. Henry et H.-R. Schwyzer, Tomus II. Enneades IV-V, accedunt Plotiniana Arabica quae anglice vertit G. Lewis, Paris, Desclée de Brouwer, 1959 (the text quoted, p. 487).

9 In particular, Zimmermann points to the Arabic translation of a Byzantine paraphrasis of Aristotle's De Anima, on which called attention Endress in his Proclus Arabus, and which has been recently edited by R. Arnzen, Aristoteles' De Anima. Eine verlorene spätantike Paraphrase in arabischer \& persischer Überlieferung. Arabischer Text nebst Kommentar, quellengeschichtlichen Studien \& Glossaren, Leiden, Brill, 1998 (Aristoteles Semitico-Latinus, 9). An overview of the texts translated and circulating within the circle of al-Kindī can be found in Endress, The Circle of al-Kindī. See also D. Gutas, Greek Thought, Arabic Culture. The Graeco-Arabic Translation Movement in Baghdad and Early Societ) (2nd-4th/8th10th centuries. London 1998, in part. pp. 141-150. I have argued in favour of Kindi's authorship of the Prologue to the pseudo-Theology of Aristotle in Al-Kindi on the Subject-Matter of the First Philosophy: Direct and Indirect Sources of alFalsafa al-ūlā, Chapter One, in Was ist Philosophie im Mittelalter? Akten des X. Internationalen Kongresses für mittelalterliche Philosophie der Société Internationale pour l'Étude de la Philosophie Médiévale 25. bis 30. August 1997 in Erfurt. Herausgegeben von J. A. Aertsen und A. Speer, Berlin - New York, de Gruyter, 1998, pp. 841-855.

10 Aristotle was indicated as the author not only of the excerpta from Plotinus' Enneads, but also of the reworking of Proclus' Elements of Theology: the Liber de Causis bears in its most ancient Arabic manuscript (Leiden, Bibliotheek der Rijksuniversiteit, Or. 209) the title K. al-ïdäh li-Aristütälis fīl-hayr al-mahd (see R.C. Taylor, The Liber de Causis (Kalām fi mahd al-hayr). A Study of Medieval Neoplatonism, Doctoral Dissertation University of Toronto, Toronto 1981, p. 106-107).

11 Against the hypothesis of a conscious forgery lying behind the attribution to Aristotle of Neoplatonic materials, Zimmermann contends that «Those around Kindī evidently perceived Greek philosophy in terms of the Aristotelian curriculum of late antiquity. The theology that was its goal accordingly was Aristotle's theology. But where in Aristotle, the freshly recruited student of philosophy might ask, is his theology? His Metaphysics, a few sketchy passages apart, is about a host of other things. Those around Kindī knew that there was no further work by Aristotle devoted to theology. Kindi expressly says that the Metaphysics is Aristotle's only book on metaphysics ('things incorporeal'). Apparently, their answer was that the theology sketched by Aristotle had been elaborated by later Greek philosophers such as Plotinus, whose accounts they united into a compilation under the title of 'Theology' -or, indeed, of 'Aristotle's Theology'. Plotinus's theology could be regarded as Aristotelian in the sense that, like Aristotle's, it exemplified the natural theology of the philosophers, not the scriptural theology of Islam or Christianity» (Zimmermann, «The Origins of the so-called Theology of Aristotle», p. 122). 
Harmony between Plato and Aristotle, ${ }^{12}$ according to which the pseudo-Theology provides a testimony of the deep coherence not only between Aristotle and Plato, but also between the entire philosophical tradition stemming from Greece and the Qu'ranic revelation. It seems that the pseudoTheology of Aristotle was read as crowning the theological part of Aristotle's metaphysics still within the time of Ibn Sinna and even later, as we may learn from the Treatise on metaphysical science (Kitāb fi 'ilm $m \bar{a}$ ba'd $a l-t a b i{ }^{\prime} a$ ) by the physician and philosopher 'Abd al-Lațîf ibn Yüsuf alBaggdādī (1162-1231), who, two centuries later than Ibn Sīnā, locates it as the conclusion of his companion on metaphysics. ${ }^{13}$

Ibn Sinnā's Notes on the pseudo-Theology' of Aristotle ${ }^{14}$ belonged in the almost completely lost Kitāb al-Inșä wa-l-Intișāf, ${ }^{15}$ the Book of fair judgment which was meant, according to Ibn Sinā's

12 Al-Fāräbī, L'harmonie entre les opinions de Platon et d'Aristote (K. al-ğam 'bayna ra'yay al-hakīmaynn, Aflätün al-ilähī wa-Arisțîtuatliss), ed. F.M. Najjar - D. Mallet, Damas, Institut Français de Damas, 1999.

13 This extremely interesting work, which is still unpublished as a whole, contains a compendium of Aristotle's Metaphysics, except Book Lambda, which is dealt with at more length and on its own, immediately after the compendium of the Metaphysics. The compendium of Aristotle's Book Lambda is followed by the one of Alexander of Aphrodisias' De providentia. The compendium of the Liber de causis follows, and also the one of twenty propositions drawn from Proclus' Elements of Theology; intermingled with five among the Questions of Alexander. Finally, al-Bağdādi summarizes the pseudo-Theology of Aristotle. Only the chapters where al-Bagidādi deals with books Alpha - alpha elatton and Lambda of the Metaphysics and with the Liber de causis have been edited and/or translated until now: see on books Alpha - alpha elatton A. Neuwirth, «Nèue Materialen zur arabischen Tradition der beiden ersten Metaphysik-Bücher», in Welt des Islams, 18 (1977-78), pp. 84-100; on book Lambda, see A. Neuwirth, 'Abd al-Latîf al-Bafg̈dädī's Bearbeitung von Buch Lambda der aristotelischen Metaphysik, Wiesbaden, Steiner, 1976; on the Liber de Causis, see R.C. Taylor, "Abd al-Latif alBaghdadi's Epitome of the Kalam fi Mahd al-Khayr (Liber de causis)", in Islamic Theology and Philosophy: Studies in honor of George F. Hourani, Albany, SUNY Press, 1984, pp. 286-323. On al-Bağdādī's compendium of the twenty propositions of the Arabic Elements of Theology, see Endress, Proclus Arabus, pp. 33-43.

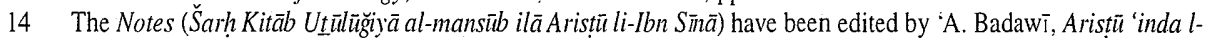
'Arab. Dirāsat wa-nușuș gạayr manšüra, I, Cairo, Maktabat al-Nahụat al-Miṣrìya, 1947, pp. 37-74 (Dirāsāt Islāmìyya, 5). See also the French translation by G. Vajda, «Les notes d'Avicenne sur la 'Théologie d'Aristote'», Revue Thomiste, 59 (1951), pp. 346-406, and L. Gardet, «En l'honneur du millénaire d'Avicenne. L'importance d'un texte nouvellement traduit», in Revue Thomiste, 59 (1951), pp. 333-345 (repr. with the title «Avicenne commentateur de Plotin» in Études de philosophie et de mystique comparées, Paris, Vrin, 1972, pp. 135-146 (Bibliothèque d'Histoire de la Philosophie). The Notes have been published by Badawī, from the ms Cairo, Dăr al-kutub, Hikma 6, a collection of texts belonging to the Aristotelian tradition, about which see D. Gutas, «Notes and texts from Cairo manuscripts, II: texts of Avicenna's library in a copy by 'Abd al-Razzāq as-Signāhā̄», in Manuscripts of the Middle East, 2 (1987), pp. 8-17, especially pp.12-13, where the author lists

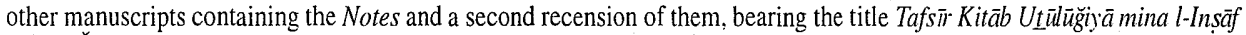
'an aš-Šayh... Ibn Siñā. Among the works contained in the Cairo ms and edited by Badawī in Aristū 'inda l-'Arab, there are an anonymous translation of chapters 6-10 of Book Lambda of Aristotle's Metaphysics, Themistius' paraphrasis of Book Lambda, Ibn Sinnā's notes on Lambda, on the pseudo-Theology and on the De Anima, and some treatises by Alexander of Aphrodisas or attributed to him. According to Gutas, Avicenna and the Aristotelian Tradition. Introduction to reading Avicenna's philosophical works, Leiden, Brill, 1988, p. 138, the two commentaries on the Theology Ibn Sinna is credited with - the Sarh edited by Badawi and the Tafsir - are «two partially overlapping recensions». The two texts «may be disciples' notes taken down from a lecture given by Avicenna, or copies from Avicenna's original draft by two different disciples, or possibly copies of each other at some unspecified remove».

15 The appartenance to the K. al-Insäf of the Notes on the pseudo-Theology of Aristotle as well as of those on Book Lambda of the Metaphysics is stated by the Cairo ms quoted in the previous note: see Badawī, Aristī 'inda l-'Arab, p. 37.1 (notes on the pseudo-Theology) and p. 22.1 (notes on Book Lambda). As for the notes on Aristotle's De Anima, which follow those on the pseudo-Theology' (see Badawī, Aristū 'inda l- 'Arab, pp. 75-112), the ms does not mention the K. al-

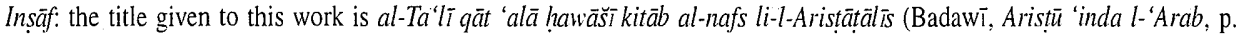
75.1) but Badawi claimed, chiefly on the basis of the affinity in structure, that it belonged in the K. al-Insäf as well (Introduction, p. 28). Badawi was followed in this by S. Pines, «La 'Philosophie Orientale' d'Avicenne et sa polémique contre les Bagdadiens», in Archives d'Histoire doctrinale et littéraire du Moyen Age, 19 (1952), pp. 1-37, in part. p. 10 n. 
own words in the Letter to al-Kiy $\bar{a},{ }^{16}$ to establish the correct exegesis of many difficult Aristotelian tenets about which the so-called "Western" school -the Christian commentators of Aristotle at Bagdad - and the "Eastern" one - Ibn Sīnā himself - were at variance. ${ }^{17}$ In his comprehensive study on the composition and history of the pseudo-Theology of Aristotle, ${ }^{18}$ Zimmermann takes into account Ibn Sinā's Notes and concludes that he made use of its original version, namely, the one which was produced within the circle of al-Kind $\overline{1}$, and not of the so-called "longer version", namely, the one which gave rise to the Latin translation, and which bears additions probably inspired by ismā' 1 li thought. ${ }^{19}$ Also, Zimmermann discusses the issue of the skepticism about the pseudoTheology' which apparently transpires from Ibn Sinnā's Letter to al-Kiy $\bar{a}$, and concludes that he held no doubts that the pseudo-Theology belonged to Aristotle's school, if not that it was written by Aristotle himself. ${ }^{20}$ More important for our purposes here, Zimmermann observes that «Avicenna's references imply a canon of sources; a canon concluded, as he indicates in his Letter to al-Kiya (...), by the Uthülijijy, $\bar{a}$; a canon similar, therefore, to that charted by Baghdadi's Metaphysics». ${ }^{21}$

3 and p. 21. Kraus, «Plotin chez les Arabes» (quoted before, n. 3), p. 274, dealt with the Notes as with a "chapter" of the K. al-Inşäf; on the contrary, Gardet, La pensée religieuse d'Avicenne (quoted before, n. 1), p. 22, was cautious about the appartenance to the $K$. al-Insäf of the Notes on the pseudo-Theology; Gutas, Avicenna and the Aristotelian tradition, pp. 137-139, maintains that the notes on Book Lambda and on the pseudo-Theology did belong in the K. al-Insäf, whereas the notes on the De Anima were marginalia in the proper sense.

16 The Letter to al-Kiy ā was discovered by Paul Kraus in the Cairo ms mentioned before, n. 14, and has, been edited by Badawī, Aristī 'inda l-'Arab, pp. 120-122. See the English translation by Gutas, Avicenna and the Aristotelian tradition, pp. 60-64, from which I quote here the passage containing the mention of the Notes on the pseudo-Theology: «I had composed a book which I called Fair Judgment. I divided scholars into two groups, the Westerners and the Easterners, and I had the Easterners argue against the Westerners until I intervened to judge fairly when there was a real point of dispute between them. This book had contained approximately twenty-eight thousand questions. I commented clearly on the difficult passages in the original texts up to the end of the Theologia Aristotelis, despite the fact that the Theologia is somewhat suspect, and I talked about the oversights of the commentators» (pp. 63-64).

17 The demonstration of this point - against the previous view that the "Westerners" Ibn Sinā alluded to were the Greek commentators of Aristotle and the "Easterners" were the Arab ones - was made by Pines, "La "Philosophie Orientale' d'Avicenne et sa polémique contre les Bagdadiens», passim. See also H.V.B. Brown, "Avicenna and the Christian philosophers in Baghdad», in Islamic Philosophy and the Classical Tradition. Essays presented (...) to Richard Walzer ed. by S.M. Stern, A. Hourani and H.V.B. Brown, Oxford, Cassirer, 1972, pp. 35-48. For the passage of the Letter to al-Kiy ā where Ibn Sinā mentions the scope of the K. al-Inșāf, see above, n. 16, where the translation by Gutas is quoted. According to al-Qifțī and Ibn Abī Ușaybi 'a, Ibn Sīnā's Kitäb al-Inșäf wa-l-Intisăäf contained twenty volumes and was completely lost in the sack of Ispahan; but according to Ibn Sinnā' biographer Bayhaqī, something of it survived. In fact, Paul Kraus was able to find in the Cairo ms mentioned before, note 14 , three items belonging in the $K$. al-Insäf. The surviving fragments of the Kitäb al-Inșäf and the testimonia about it are discussed by Gutas, Avicenna and the Aristotelian tradition,
pp. 130-140.

18 See note 6.

19 On the so-called "longer version" see Aouad, «La Théologie d'Aristote et autres textes du 'Plotinus Arabus'», pp. 564-570.

20 Kraus, «Plotin chez les Arabes», p. 273, interpreted Ibn Sinā's statement that in the K. al-Inșäf he discussed the philosophical works until the end of the Theology, «for all one may find to object» in it (Letter to al-Kiyäa in Badawi, Aristi $\bar{u}$ 'indal-'Arab, p. 121.20; transl. Zimmermann, p. 184; Gutas translates «despite the fact that the Theologia is somewhat suspect»: see above, n. 16) in the sense that Ibn Sinnā was doubtful about Aristotle's authorship of the Theology ascribed to him. On the contrary, Zimmermann, «The Origins of the so-called Theology of Aristotle», p. 184, maintains that «Avicenna seems far from rejecting the ascription of [the Theology] to Aristotle. At the very least, he seems to accept the Kindi-circle concept of the *Theology' as a supplement to Aristotle's Metaphysics», and explains Ibn Sinā's cautious formula as a doubt related to the chaos of the text (p. 184).

21 Zimmermann, «The Origins of the so-called Theology of Aristotle», pp. 183-184; the quotation, p. 184. 
Now, if the philosophical materials on the Greek doctrines about the first principles of the universe Ibn Sīnā had at his disposal were arranged into a canon similar to the "Kindian" one reflected in al-Bağdādī's Kitāb fị' ilim mā ba 'd al-tabi 'a, it seems that one might assume without too much questioning that, since the latter contains the Liber de Causis, Ibn Sinna too had access to it. On the contrary, some scholars in the past insisted upon the fact that he apparently does not make any use of the De causis, and took this as proof of the alleged lack of the De causis from the scene of Islamic philosophy of the classical age in the East. There would be little point in recalling here the arguments of those scholars who wanted to locate the composition of the Liber de Calsis in the XII Century Muslim Spain, a thesis which was ruled out by Endress' Proclus Arabus in 1973. ${ }^{22}$ But, even once established the origin of the Liber de Causis in the IX Century Bagdad on such a firm basis as its stylistic and doctrinal affinities with other works produced within the circle of al-Kindī, the alleged lack of evidence of any knowledge whatsoever of the Liber de Causis in the works of al-Fārābī or Ibn Sīnā did not cease to trouble the scholars working in the field ${ }^{23}$ Richard C. Taylor proposed a solution for this baffling fact which pivots on the possibility that the much wider and more famous pseudo-Theology obscured the Liber de Causis and made in some sense useless, in alFārābī or Ibn Sinnā's eyes, to have recourse to it, since they had the pseudo-Theology' at their disposal. ${ }^{24}$ In what follows, I would like to add a few pieces of evidence to the dossier of Ibn Sinā's Neoplatonic sources, discussing four passages from the Metaphysics of the Kitäb al-Šifä ${ }^{25}$ which are reminiscent, so it seems to me, not of the pseudo-Theology or of another unidentified Neoplatonic text, but of the Liber de Causis itself.

22 Endress' compelling arguments locating the composition of the Liber de Causis within the circle of al-Kindi were confirmed later on by E.K. Rowson, «An unpublished work by al-'Ämirī and the date of the Arabic De causis», in Journal of the American Oriental Society, 104 (1984), pp. 193-199. For the status quaestionis on the Liber de causis see now C. D:Ancona - R.C. Taylor, «Le Liber de Causis», in Dictionnaire des Philosophes Antiques publié sous la direction de R. Goulet, Supplément au vol. I publié par J.-M. Flamand, forthcoming.

23 H.A. Davidson, Proofs for Eternity; Creation and the Existence of God in Medieval Islamic and Jewish Philosophy; New York - Oxford, Oxford U.P., 1987, p. 294, suggests that the proof Ibn Sinä advances for the existence of the necesse esse rests on Neoplatonic doctrines transmitted through the De causis, but this claim is approached with prudence by R.C. Taylor in his review of Davidson's book, published in Speculum, 65 (1990), pp. 646-648. 'A. Badawi, La transmission de la philosophie grecque au monde arabe, Paris, Vrin, 1968, pp. 68-69, has recourse to Ibn Sīnä's terminology: his definition of the First Principle as "al-ganial-tamm, the perfectly rich", is reminiscent of the definition of the First Cause as "al-ganä' al-akbar, the greatest richness", which appears in De causis 20[21], p. 98.2 Bardenhewer; p. 22.2 Badawī (see below, n. 25). According to R.C. Taylor, «The Kalām fïmaḥ al-khair (Liber de Causis) in the Islamic philosophical milieu», in Pseudo-Aristotle in the Middle Ages. The Theology and other texts (see note 6), pp. 37-52, especially p. 46 n. 34, this terminological argument cannot count in itself as a proof of Ibn Sinā's knowledge of the Liber. J.R. Michot, La destinée de l'homme selon Avicenne. Le retour à Dieu (ma'äd) et l'imagination, Leuven, Peeters, 1986, pp. 59-60, points to the similarity between Ibn Sinā's threefold distinction "eternity - perpetuity - time" and the doctrine of the De causis (cf. prop. 29[30], p. 112.9-113.8 Bardenhewer, p. 30.1-7 Badawi; for the full reference to the editions of the De causis see below, note 25).

24 Taylor, «The Kaläm fímahd al-khair (Liber de Causis) in the Islamic philosophical milieu», p. 43.

25 Ibn Sinā's Metaphysics will be quoted by page and line of the Arabic and Latin texts: Ibn Sinā, Al-Šsfä'. AlIlāhñāit (I), texte établi et édité par G.C. Anawati, S. Dunyā, préface par I. Madkour; (II) texte établi et édité par M.Y. Moussa, S. Dunyā, S. Zayed, Le Caire, Organisation Générale des Imprimeries Gouvernamentales, 1960; Avicenna Latinus. Liber de philosophia prima sive de scientia divina, édition critique de la traduction latine médiévale par S. van Riet, I-IV, Louvain-Leiden, Peeters-Brill 1977; V-X. Louvain-Leiden, Peeters-Brill, 1980 (Avicenna Latinus, 3-4). See also the French translation, Avicenne. La Métaphysique du Shifā', introd., trad. et notes par G.C. Anawati, I-II, Paris, Vrin, 1978-1985 (Études Musulmanes, 21; 27). The Liber de Causis will be quoted by page and line of the two editions of the Arabic text avai- 
(i) VIII 4, p. 347.10 (p. 402.48-49) - The crucial fourth chapter of treatise VIII deals with the attributes (sifät, proprietates) of the necesse esse. ${ }^{26} \mathrm{Ibn}$ Sinna opens the chapter by recalling the point he has just established at the end of chapter 3, namely, that the first agent principle (mabda' awwal fa $a$ il, principium primum agens) cannot be but one. ${ }^{27}$ True, he is talking in this chapter of the necesse esse, and the argument he has developed from the beginning of treatise VIII concerns the first principle in the series of efficient causes. But the referential identity between the principium primum agens and the necesse esse had already been established when, in treatise VI, Ibn Sīnā argued that in the metaphysical discourse - at variance with what happens in the physical one - the agent principle is not confined to the status of the beginning of movement, but is the true principle of being (mabda' al-wü̆̈̆d), i.e., the unique Creator. ${ }^{28}$ If so, the argument for the unicity of the first agent principle concludes also in the unicity of the necesse esse. Once recalled that the necesse esse cannot be but one, ${ }^{29}$ Ibn Sina a proceeds to the next move, namely, to establish that the attributes which necessarily follow from the very fact of its being the necesse esse do not involve any composition whatsoever in it. ${ }^{30}$ Notwithstanding the manifest Neoplatonic inspiration of this claim, the argument supporting it parts company with the Neoplatonic doctrine of the lack of any relationship whatsoever in the First Principle. Whereas in Greek Neoplatonism, both for Plotinus and Proclus, the relationship between the derivative realities and the First Principle is univocal - in other terms, the derivative realities are related to the First Principle, but the reverse is not true- ${ }^{31}$ according to Ibn Sīnā the First Principle does have a relationship (idăfa, relatio) with its derivatives. But this by no means implies that the First Principle is multiple or composite: its relationes are but comitantes essentiae (lawāzim li-l-dāt) and causatae essentiae, which means that they come after the essence of the First Principle and are neither fundamentals nor parts of it. ${ }^{32}$ After having quickly solved a difficulty, ${ }^{33}$ Ibn Sina an proceeds to the crucial point of the whole chapter: the First Principle does not possess a quidditas (māhĩya) but its own anitas (annīya). ${ }^{34}$ In order to support this claim, he embarks upon an argument whose main steps are the following: the very notion of necesse esse indicates the quiddity of that principle, in precisely the same way as 'one' or 'man' indicate the quiddity of those realities. ${ }^{35}$ But once we take into account the nature of the First Principle of the uni-

lable in print: O. Bardenhewer, Die pseudo-aristotelische Schrift Ueber das reine Gute bekannt unter dem Namen Liber de causis, Freiburg im Breisgau, 1882 (Nachdruck... Minerva GmbH, Frankfurt a. Main, 1961); 'A. Badawī, Al-Aflătūñ̄̃a almuhdata 'inda l-'Arab, Cairo, Maktabat al-nahdat al-miṣrìya, 1955, pp. 1-33 (Dirāsāt Islāmìya, 19). The Latin text of the De causis will be quoted from A. Pattin, «Le Liber de causis. Édition établie à l'aide de 90 manuscrits avec introduction et notes», in Tijdschrift voor Filosofie, 28 (1966), pp. 90-203. The English translation quoted is by Taylor, The Liber de Causis (Kaläm fi mahd al-hayr). A Study of Medieval Neoplatonism, quoted above, n. 10.

26 VIII 4, Arabic: p. 343.7-349.6; Latin: p. 397.53-404.1.

27 VIII 3, Arabic: p. 342.1; Latin: p. 395.12-13.

28 VI 1, Arabic: p. 257.13-16; Latin: p. 292.17-24.

29 VIII 4, Arabic: p. 343.10-11; Latin: p.397.55-58.

30 VIII 4, Arabic: p. 343.11-15; Latin: p. 397.58-398.65.

31. See for instance VI 9[9], 3.49-54; Proclus, El. th. 116 and 122.

32 VIII 4, Arabic: p. 343.16-344.5; Latin: p. 398.65-77.

33 To admit that the First Principle has relationes which are causatae essentiae seems to open the way to an infinite regress, in so far as what relies each of them to its cause is, in turn, another relatio. Ibn Sinā claims to have already solved this difficulty before (III 10), where he argued that relationship cannot proceed to the infinite.

34 VIII 4, Arabic: p. 344.10; Latin: p. 398.83-399.84.

35 VIII 4, Arabic: p. 344.11-14; Latin: p.399.85-90. 
verse, we realize that those philosophers who conceived of it as unique -discarding those who thought that there were many first principles - did so either because they sought to locate the first principle in this or that element and said that it was one, or because they thought that the one itself (dātal-wähid) was the First Principle. This very fact shows that a difference exists between the quiddity which has 'unity' or 'being' as its predicates, and the one, or being, taken in itself, in so far as it is 'one' or 'being'. ${ }^{36}$ This is why in the First Principle no composition whatsoever takes place. If we assume, for the sake of argument, that the quiddity 'man' exists by necessity, we still have $a$ quiddity' which exists by necessity: not so in the case of the First Principle. Far from being a quiddity which possesses the necesse esse, the First Principle is the necesse esse, and nothing more, unless one is ready to accept that it receives the necesse esse from another principle than itself, a consequence which goes against its very definition. ${ }^{37}$ Another point Ibn Sīnā wants to establish is

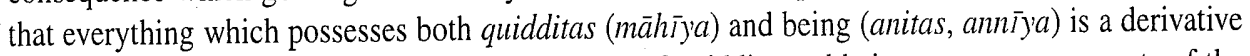
reality. The point is made by refusing to conceive of quiddity and being as two components of the given thing. 'Being' can either accompany a quiddity, and in this case the thing is, or not accompany the quiddity, and in this case the thing is not; which implies that being comes from something else than the given quiddity. This is why Ibn Sinā calls it a comitans (lāzim) of the given quiddity, namely, something which is not a part of its definition or nature but can accompany it, in which case the quiddity turns to be a real being. The hypothesis of a quiddity which in itself, i.e., in its very nature or definition, necessarily implies being is ruled out as absurd: such a quiddity would be anterior to its own being, in so far as it would receive it from itself. But if each and every quiddity which possesses being has it from another principle than itself, this proves the demonstrandum: everything which possesses being is a derivative reality. «Igitur omne habens quidditatem causatum est; et cetera alia, excepto necesse esse, habent quidditates quae sunt per se possibiles esse, quibus non accidit esse nisi extrinsecus». ${ }^{38}$

The conclusion Ibn Sinā draws from this argument, so it seems to me, is reminiscent of the Liber de Causis. He says:

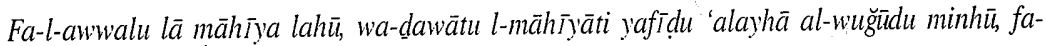
huwa muı̆arradu l-wuğŭdi (...).

Primus igitur non habet quidditatem, sed super habentia quidditates fluit esse ab eo; ipse igitur est esse expoliatum $(. . .)^{39}$

36 VIII 4, Arabic: p. 344.14-345.5; Latin: p. 399.91-99.

37 VIII 4, Arabic: p. 345.6-346.3; Latin: p. 399.00-400.20.

38 VIII 4, Arabic: p. 346.15-347.9; Latin: p. 401.33-402.47. The quotation, p. 347.8-9 (Arabic); p. 402.44-47 (Latin). The argument I have summarized received much attention in scholarship, from Goichon, La distinction de l'essence et de l'existence d'après Ibn Siñā (quoted above, n. 1), pp. 343-354, onwards: see G.F. Hourani, «lbn Sinnā on necessary and possible existence», in Philosophical Forum, 4 (1972), pp. 74-86; H.A. Davidson, «Avicenna's proof of the existence of God as a necessarily existent being», in Islamic Philosophical Theology ed. by P. Morewedge, Albany, SUNY Press, 1979, pp. 165-187; Janssens, Avicenna: tussen neoplatonisme en islam, Ph.D. Leuven 1984 (quoted above, n. 1), p. 128-133; D.B. Burrell, «Essence and existence: Avicenna and Greek philosophy», in MIDEO, 17 (1986), pp. 53-66. For further information see J.L. Janssens, An Annotated bibliography on Ibn Sinä (1970-1989). Including Arabic and Persian publications and Turkish and Russian references, Leuven, University Press, 1991, and Id., An annotated bibliography on Ibn Sïnä: First Supplement (1990-1994), Louvain-la-Neuve, FIDEM, 1999.

39 VIII 4, Arabic: p. 347.10; Latin, p. 402.48-49. 
The idea that the First Principle does not have any form and that for this reason is 'pure being' clearly echoes the Neoplatonic doctrine of the One, reshaped in the peculiar form it received in the Arabic version of Plotinus' and Proclus' writings. At variance with the Greek original texts, in the Arabic version of their works a typical doctrine was worked out, a doctrine which conflates the ori-

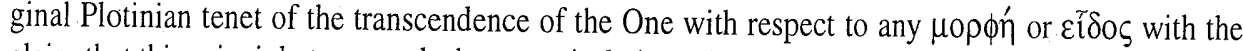
claim that this principle transcends them precisely in so far as it is 'pure Being', anniyy (or huwīya) faqat. This doctrine is non-Plotinian and non-Proclean, and two attempts have been made in order to account for its presence in the Arabic Neoplatonic texts, which trace back both to Greek sources. Some scholars (Pines, Thillet, Taylor) think that this doctrine traces back to Porphyry, who parted company from Plotinus in his own commentary on the Parmenides and claimed that the One is $\alpha$ vito

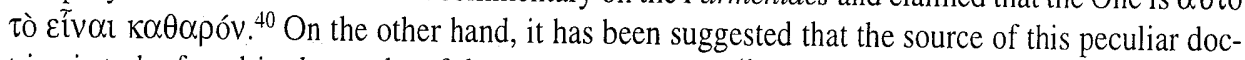
trine is to be found in the works of the pseudo-Dionysius. ${ }^{41}$ At all events, in the three main Arabic Neoplatonic texts - the reworking of the Plotinian treatises, the Arabic translation of Proclus' Elements of Theology' edited by Endress, and the Liber de Causis- the topic of the transcendence of the One with respect to intelligible reality is coupled with the idea that it is so precisely because the true One is 'pure Being' as well. In the above-mentioned passage, Ibn Sinnā does not quote literally one or other of the Arabic Neoplatonic sources which are likely to lie in the background of his assessment: the terminology he adopts is his own, as is clearly indicated by his favourite expression muğarrad al-wuğ̆̆d, esse expoliatum, a syntagma which reformulates in Ibn Sīnā's proper terms the definition of the First Principle as 'pure Being' - annīy a faqat (or huwīya faqat: literally, 'solely being') - of the Arabic Neoplatonica of the circle of al-Kindi . $^{42}$ The transcendence of the First Principle with respect to everything which possesses quiddity is reformulated by Ibn Siñā in his own terminology as well. Not that the term māhi $\bar{y}$ 'a does not appear in the Arabic Neoplatonica; ${ }^{43}$ but it is not used to deny the presence of quiddity in the First Principle: in order to express this idea, the Arabic Plotinus has recourse to the typical couple hilya wa-süra, "shape and form"; the Arabic Proclus, at times, makes use also of kayfì̀ $a$, "quality", for this purpose. ${ }^{4}$ But even though Ibn Sinnā

40 P. Thillet, «Indices porphyriens dans la pseudo-Théologie d'Aristote», in Le néoplatonisme. Actes du Colloque international du CNRS, Paris, Éd. du CNRS, 1971, pp. 293-302; S. Pines, «Les textes arabes dits plotiniens et le courant "porphyrien" dans le néoplatonisme grec», ibid., pp. 303-317; R.C. Taylor, «Aquinas, the Plotiniana Arabica and the metaphysics of being and actuality», in Journal of the History of Ideas, 59 (1998), pp. 217-239.

41 See my «Esse quod est supra aeternitatem. La cause première, l'être et l'éternité dans le Liber de causis et dans ses sources», in Archives d'Histoire doctrinale et littéraire du Moyen Age, 59 (1992), pp. 41-62; «La doctrine néoplatonicienne de l'être entre l'Antiquité tardive et le Moyen Age. Le Liber de causis par rapport à ses sources», in Recherches de Théologie Ancienne et Médiévale, 59 (1992), pp. 41-85 (better printed in Recherches sur le Liber de Causis, Paris, Vrin, 1995, pp. 121-153); «L'influence du vocabulaire arabe: "Causa prima est esse tantum"», in L'élaboration du vocabulaire philosophique au Moyen Age. Actes du Colloque International organisé par la SIEPM, Louvain-la-Neuve/Leuven, 12-14 sept. 1998, p. 51-97 (forthcoming).

42 For the syntagma anñ̄'a faqat in the Arabic Neoplatonica see Badawī, Aflīt in 'inda l- 'Arab, pp. 67.14; 71.15, 16; $147.14,15 ; 160.12 ; 161.7 ; 179.2 ; 197.9$; for the syntagma huwña faqat, see p. 161.2 .

43 In the Arabic Plotinus mähña is not referred to the First Principle but to soul: see Badawī, Aflutintn 'inda l- 'arab,

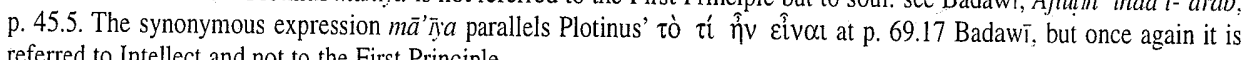
referred to Intellect and not to the First Principle.

44 For the typical couple hilya wa-sïra see Endress, Proclus Arabus (quoted above, n. 5), pp. 134-139; 212. The term kayfīa is not so often used in the Arabic Plotinus: see Badawī, Aflütīn 'inda l-Arab, pp. 38.9; 46.2, 6; 94.11; 128.15-16. Kayfña parallels Plotinus' $\pi$ otótns at pp. 45.12; 46.1 and 13. In the Arabic version of prop. 73 of Proclus' Elements of Theology an interpolated passage claims that the First Cause is huwña faqat because it has no kayfña whatsoever: see Endress, Proclus Arabus, p. 25.18 [Arabic text]. 
is not quoting this or that passage verbatim, he is not echoing a generic inspiration either. The tenet that the First Principle has no form whatsoever, indeed is pure being, and that precisely for this reason it pours forth being onto all things, is by no means unprecedented. In the Liber de Causis, this doctrine is stated as follows:

wa-l-'aqlu dū hilyatin ${ }^{45}$ li-annahū annìya wa-șirra wa-kad̄alika l-nafsu d̄ātu hilyatin wa-l-țabi'atu dàtu hilyatin wa-laysa li-l-illati l-ïlā hilyatun li-annahā anñ̄yatun faqat. Fa-in qăla qă'ilun lā budda min an yakūna lahā hilyatun, qulnā hilyatuhā lä nihāyatuhāa

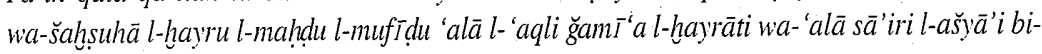
tawassuti l-'aqli. ${ }^{46}$

And the intelligence possesses shape because it is being and form, and likewise soul possesses shape and nature possesses shape, but the First Cause does not have shape because He is only being. So if someone says: He must have shape, we say: His shape is infinite and his essential nature is the Pure Good pouring forth all goods on the intelligence and on all other things through the mediation of intelligence (transl. Taylor). ${ }^{47}$

True, the idea that the First Principle is 'pure Being' is not exclusive of the Liber de Causis: on the contrary, it is common to all the Neoplatonic texts which are likely to have been available to Ibn Sinnā, and in particular it occurs in the pseudo-Theology' he commented upon. ${ }^{48}$ Moreover, the topic of the shapeless nature of the First Principle seems to have been worked out in the Arabic Plotinus, and transmitted from the Arabic Plotinus to the Arabic Proclus, namely, to the Arabic translation of the Elements of Theology and to the Liber de Causis. ${ }^{49}$ So, one is spontaneously inclined to say that it was in the pseudo-Theology that Ibn Sinā found the doctrine of the passage quoted above, and that there is no reason to have recourse to the Liber de Causis in order to account for it. But a closer inspection shows that he is likely to have in his memory the passage of the De causis.

45 Both Bardenhewer and Badawi print here kullīa ("totality"). The correct reading hilya ("shape", "form") was recognized by Rosenthal, «AššŠayh al-Yūnānī and the Arabic Plotinus Source» (quoted above n. 4), p. 469 and by Endress, Proclus Arabus, pp. 136, 212; see also G. Serra, «Alcune osservazioni sulle traduzioni dall' arabo in ebraico e in latino del De generatione et corruptione di Aristotele e dello pseudo-aristotelico Liber de Causis», in Scritti in onore di Carlo Diano, Bologna, Patron, 1975, pp. 385-433, especially pp. 423-427; R.C. Taylor, «St. Thomas and the Liber de Causis on the hylomorphic composition of Separate Substances», in Medieval Studies, 41 (1979), pp. 506-513.

46 Liber de Causis, prop. 8[9], pp. 78.8-9.1 Bardenhewer, p. 12.14-17 Badawi.

47 Taylor, The Liber de Causis (Kalām fi mahd al-hayr). A Study of Medieval Neoplatonism, pp. 299-300.

48 Ibn Sinā commented upon a long passage of chapter I of the pseudo-Theology which is totally independent from Plotinus (Badawì, Aflïtīn 'inda l-'arab, pp. 25.15-28.3) and where the First Cause is said to be "first and pure Being" (al-

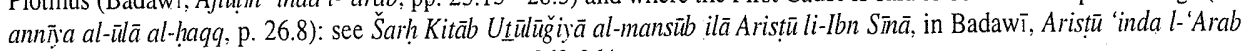
(quoted above, n. 14), p. 46.3-15; transi. Vajda, pp. 363-364.

49 I have argued in favour of this point in my «L'influence du vocabulaire arabe: "Causa prima est esse tantum"» (quoted above, n. 40), in part. pp. 77-80, on the grounds of the fact that the topic of the First Cause as annña faqat in so

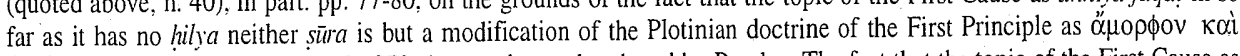
$\dot{\alpha} v \varepsilon i \delta \varepsilon 0 v$. This doctrine is typical of Plotinus and was abandoned by Proclus. The fact that the topic of the First Cause as anñ̄a faqat, having no hilya neither șüra, appears in the Arabic Plotinus and in the Arabic Proclus as well (both in the Proclus Arabus edited by Endress and in the Liber de Causis) creates a drift towards the idea that it was first worked out in the adaptation of Plotinus, and later endorsed by the translator of Proclus' Elements of Theology and by the author of the Liber de Causis. 
The passages of the Arabic Plotinus where the First Principle - be it called True One, First Cause, God Almighty, or Creator - is said to be 'pure Being' are many, ${ }^{50}$ but there is one in particular which might have inspired Ibn Sīnā. In this passage, two of the doctrinal features of Ibn Sīnā's own passage are present, namely, the shapeless nature of the First Principle (la mähìya lahü in Ibn Sīnā's account) and its denomination as 'pure Being' (muğarrad al-wuğŭd in Ibn Sīnā's account). The passage is found in the collection of the 'Sayings of the Greek sage's1 and is related to the following passage in Ennead V 1 [10], 7.20-21:

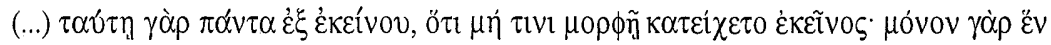

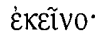

(...) for this is how all things come from him, because he is not confined by any shape; that One is one alone (transl. Armstrong).

The Arabic rendering of this passage amplifies, as usual, the Greek of Plotinus, adding both a monotheistic interpretation of Plotinus' One and a peculiar interpretation of its shapeless nature:

The First Creator does not resemble any thing, because all things are from Him and because He has no shape (hilya) and no special, inherent form (siura). The First Creator is absolutely one, i.e., He is mere being (anniya faqat) without any peculiar attribute (sifa). All attributes break forth from that being (transl. Rosenthal). ${ }^{52}$

This passage of the Arabic Plotinus counts, so it seems to me, as one of the sources of the passage of the Liber de Causis I have quoted before. ${ }^{53}$ The same addition, namely, the interpretation of the Neoplatonic One as anniy a faqat or huwiya faqat, as well as the account of this feature in terms of lack of any attribute (sifa) or quality (kayfíya), appears also in the interpolated passages which accompany the Arabic translation of props. 2, 21, 73 and 74 of the Proclus Arabus edited by Endress. ${ }^{54}$ My guess is that this topic has been worked out first in the paraphrasis of V 1[10], and that, by circulating within the circle of al-Kindī, it influenced both the translator of Proclus' Elements of Theology' and the author of the Liber de Causis. But I have two reasons for not thinking that the passage of the Arabic Plotinus preserved in the doxography of the 'Greek Sage' counts also as the source of Ibn Sinnā's statement.

First, in reading the three passages in parallel - the one from the Arabic Plotinus, the one from the Liber de Causis and the one by Ibn Siña — it is easy to see that it is only in the De Causis that

50 In addition to the passages quoted above, n. 42, see also Badawī, Aflütin 'inda l-'Arab, pp. 27.2; 51.8; 87.10;

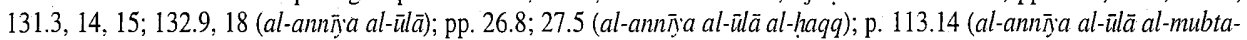

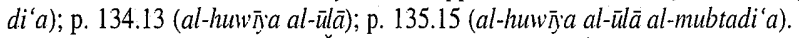

51 See Rosenthal, «Aš-Šayh̆ al-Yūnānī and the Arabic Plotinus Source» (quoted above n. 4) and Aouad, «La Théologie d'Aristote et autres textes du 'Plotinus Arabus'» (quoted above, n. 2), pp. 574-580.

52 Arabic text in Badawī, Aflütīn 'inda l-'Arab (quoted above, n. 2), p. 185.5-7 and in Rosenthal, «AššSayh al-Yūnānī and the Arabic Plotinus Source»., p. 478; transl. Rosenthal, p. 479.

53 See my "Cause prime non est yliathim. Liber de Causis, prop. 8[9]: le fonti e la dottrina», in Documenti e studi sulla tradizione filosofica medievale, 1 (1990), pp. 327-351 and note 48 above.

54 I have tried to support this claim in the paper quoted above, n. 48. 
all the three elements which do appear in Ibn Sinnā's statement are present together, namely (i) the idea that the First Principle is 'pure Being', (ii) because it has no quiddity, (iii) and that it pours forth being onto things which possess quiddity. Items (i) and (ii) appear in the Arabic Plotinus. In the passage from the Liber de Causis the items (i)-(iii) appear together, and for this reason it seems sensible to accept it as the source of Ibn Sinnā's statement. True, one might object that in Ibn Sīnā's passage we are told that the First Principle - Pure Being pours forth being onto the things which possess quiddity, and in the passage from the Liber de Causis we are told that it pours forth "all the goods" onto the derivative realities. But the idea that the First Cause, which is only being and pure being, pours forth being onto the derivative realities which are endowed by this or that form -life, intelligence, movemen - by subordinate immaterial principles is a typical feature of the Liber de Causis. This topic had few chances of appearing as such in the Arabic Plotinus, in so far as it is an interpretation of a typical Proclean tenet, namely, the causality of the three main principles öv, $\zeta \omega r$ and voṽc. In his reworking of prop. 138 of Proclus' Elements of Theology, the author of the Liber de Causis interprets Proclus' öv as if it were the 'pure Being' which, in his eyes, merges with the True One and is but the First Cause, or God himself. Of course, it is not so for Proclus; but the reworking of Proclus' proposition allows the author of the De causis to conclude his proposition 17[18] with the following sentence, which has no antecedent in Greek:

We resume and say, then, that the First Entity (al-huwryat al-illa $)$ is quiescent and is the cause of causes, and if He gives all things entity (al-huwiya), He gives it in the manner of origination. The first life gives life to what is below it, not in the manner of origination, but in the manner of form. And, likewise, the intelligence gives knowledge and the other things to what is below it only in the manner of form, not in the manner of origination, because the manner of origination belongs to the First Cause alone (transl. Taylor). ${ }^{55}$

When the author of the Liber de Causis - still in a passage which has no Greek antecedent, i.e., the one quoted above from proposition 8[9] — maintains that the First Cause pours forth "all goods" onto the things which possess shape, in the light of the present passage one can confidently say that this means that it pours forth first and foremost being. Or at least so it seems in Ibn Sīnā's eyes, even though his own notion of being is obviously different from the one we can glean from the assessments scattered in the Liber de Causis, and is original to him. To sum up, I am inclined to think that Ibn Sinā's passage is redolent of the passage of proposition 8[9] of the Liber de Causis quoted above, and that in taking from it his inspiration Ibn Sinā is aware of the passage of proposition 17[18] just quoted, where the First Cause is said to pour forth being onto all its derivatives.

The second, additional reason I have for thinking that the proximate source of Ibn Sinā's tenet is the passage of the Liber de Causis, and not the passage of the Arabic Plotinus, is that the latter does not appear in the pseudo-Theology. As we have just seen, it comes from V 1[10] and is preserved in the doxography of the 'Greek Sage'. As happens in general for the entire tradition of the Arabic Plotinus, in the case of V 1[10] too one is struck by the fact that the actual remaining parts 
of the translation of treatises from Enneads IV-VI - i.e., the pseudo-Theology, the pseudo-Farabian Epistle on the Divine Science and the "Sayings of the Greek Sage" pattern. In other words, the Arabic texts preserved in the three actual testimonies of it, albeit deriving from one and the same translation - as has been shown with compelling arguments by Kraus, Rosenthal, Endress and Zimmermann- do not overlap, if not only at times and for short portions. In the case of V 1[10], the chess-board is the following:

\section{Plotinus' Treatises vs Plotiniana Arabica}

B. = 'A. Badawī, Aflītīn 'inda-l-'Arab. Plotinus apud Arabes. Theologia Aristotelis et fragmenta quae supersunt, Cairo, Dār al-Nahụat al-'Arabīya, 1966

D. $=$ F. Dieterici, Die sogenannte Theologie des Aristoteles aus arabischen Handschriften zum ersten Mal herausgegeben, Leipzig 1882 (Amsterdam, Rodopi, 1965)

L. = Plotiniana Arabica ad codicum fidem anglice vertit G. Lewis, in Plotini Opera II, Enneades IV-V ediderunt P. Henry et H.-R. Schwyzer, Desclée de Brouwer - L'Edition Universelle, Paris-Louvain 1959 ( $\mathrm{L}^{*}$ = passages of the Sayings covering the same textual portion preserved in the $p s .-T h e o l o g y$ )

R. = F. Rosenthal, «AššSayh al-Yūnānī and the Arabic Plotinus Source», Orientalia, 21 (1952), pp. 461492; 22 (1953), pp. 370-400; 24 (1955), pp. 42-65

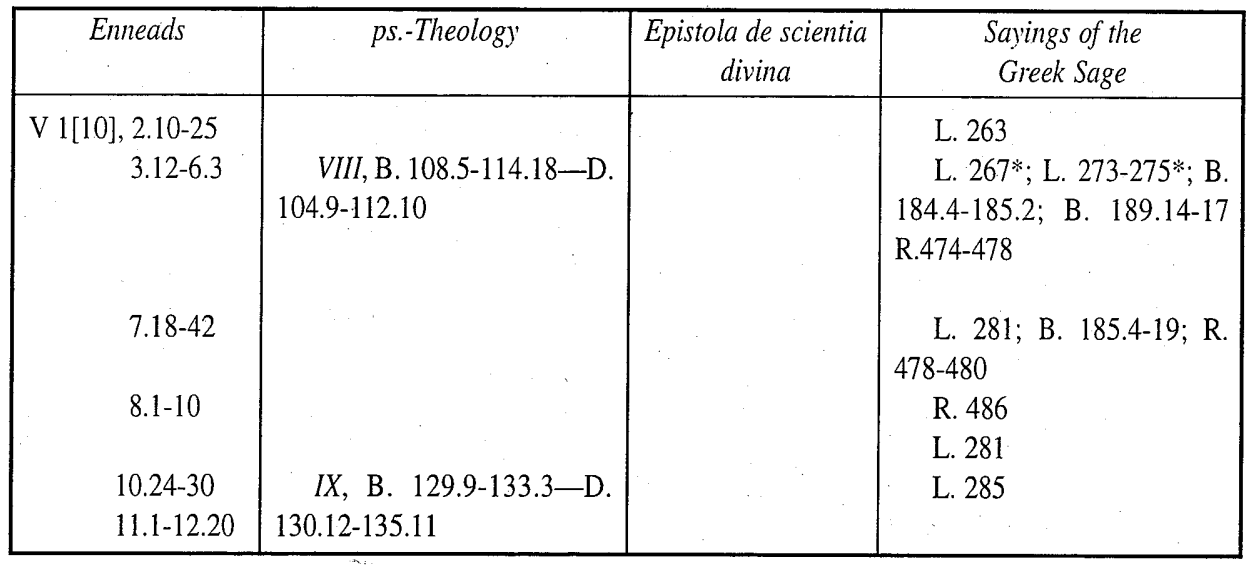

As this table shows, the passage of the 'Sayings of the Greek Sage' related to V 1[10], 7.19-20 - which inspired in all likelihood the author of the Liber de Causis for his proposition 8[9] - does not belong in those where the pseudo-Theology' and the 'Sayings of the Greek Sage' overlap.This is to say, a reader of the pseudo-Theology in the form it came down to us could not have had access to it. Ibn Sinā was such a reader, as Zimmermann contends ${ }^{57}$ and as a detailed inspection of his

56 For the three texts mentioned and the actual state of the research on each of them, see Aouad, «La Théologie d'Aristote et autres textes du 'Plotinus Arabus'» (quoted above, n. 2).

57 Zimmermann, «The Origins of the so-called Theology of Aristotle», p. 183. 
Notes confirms. Of course, the possibility exists that he had access also to other sources, preserving that part of the Arabic translation and paraphrase of V 1[10], and one should not force an argument taken from the remaining parts of the transmission, in the case of such a complex textual tradition, so many aspects of which are still obscure. But the fact remains that the passage which, in the Arabic Plotinus, resembles more to Ibn Sinā's statement does not belong in the part of the translationparaphrase he had at his immediate disposal in the pseudo-Theology of Aristotle.

As a conclusion of the analysis of the relationship among the texts which are the best candidates for having been the source of Ibn Sinnā's claim that the First does not possess quidditas and pours forth being onto the habentia quidditates, I would like to stress once again that this amounts only to stating that the passage quoted from the Metaphysics of the Kitäb al-Šifä' echoes the De causis passage. Ibn Sinnā's use of his source is free: not only the terminology is his own, but also the philosophical implications he draws from the doctrine of the Liber de Causis are original.

(ii) VIII 4, p. 348.5-6 (p. 403.69-73) — Still in the same chapter of treatise VIII, Ibn Sīnā contends that the First Principle cannot be known by means of a definition or a demonstration, in so far as it does not possess a cause:

wa-li-d̄alika fa-inna l-awwala lā fașla lahūu, wa-id lā ğinsa lahū wa-lä fașla lahū fa-lā hadda lahū, wa-lä burhāna 'alaỳhi, li-annahū lā 'illata lahü.

Et ideo non habet differentiam; quia enim non habet genus, nec habet differentiam, ideo non habet definitionem. Nec fit demonstratio de eo quia ipse non habet causam. ${ }^{58}$

The Arab philosophers were acquainted since al-Kindî's time with the idea that the First Principle transcends not only every predicative assessment, but also the ontological structure which is presupposed by predication, namely, the classification according to genera and species. ${ }^{59} \mathrm{But}$ Ibn Sinā does not limit himself to recall this topos; indeed he points to a reason why the First Principle cannot be known according to the usual way taken in demonstrative science, i.e., through a definition; and the reason given recalls, so it seems to me, the following passage of proposition 5[6] of the Liber de Causis:

Fa-min dālika șāra l-awwalu waḥdahū yafütu l-șifata wa-innamā kāna kad̄ālika li-annahü laysa fawqahü 'illatun yu'rafu bi-hā, wa-kullu šay'in innamā yu'rafu wa-yūisafu min tilqā'i 'illatihĩ fa-id̄a kāna l-šay'u 'illatan faqat wa-laysa bi-ma 'lülin lam yu 'lam bi- 'illatin ülā walā yüsafu li-annahū a' lā mina l-șifati wa-laysa yablugiuhü l-mantiqu.

58 VIII 4, Arabic: p. 348.5-6; Latin, p. 403.69-73. I owe to Marc Geoffroy the observation that the words which follow immediately in the Arabic, wa-li-dälika lä l-mm (?) lahū, should be read wa-li-dälika lā lima lahüu, and allude to opposition between $m \bar{a}$ and lima: about God, the question "lima?" cannot be asked, in so far as it does not possess a cause; by implication, it cannot be known through a burhān but only through a dalit, which is represented by God's effects.

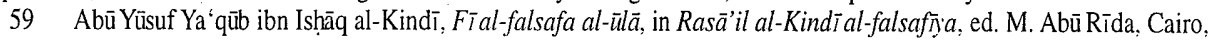
Dār al-fikr al-'arabī, 1950, p. 160.13-161.5; see also R. Rashed - J. Jolivet, Euvres philosophiques et scientifiques d'alKindī, volume II. Métaphysique et cosmologie, Leiden-Boston-Köln, Brill, 1998 (Islamic Philosophy, Theology and Science, 29), p. 95.10-19 (French transl., p. 94), and the English translation by A.L. Ivry, Al-Kindi's Metaphysics. A Translation of Ya'qüb ibn Ishāq al-Kindī's Treatise On First Philosophy (fíal-falsafah al-ülāa), Albany, SUNY Press, 1974. p. 112 . 
For this reason, therefore, the First alone came to elude description. That $<$ was $>$ so because there is no cause above Him through which He might be known and every thing is known and described only by way of its cause. Thus, if the thing is only a cause and not an effect, it is not known or described through a first cause because it transcends description and speech does not reach it (transl. Taylor). ${ }^{60}$

Of course, one might think that Ibn Sīnā is just recalling the well-known Aristotelian doctrine which is presupposed in this passage of the Liber de Causis and, in turn, in Proclus' proposition which lies in its background. ${ }^{61}$ But the fact that Ibn Sinna makes use of this Aristotelian topic in precisely the same way as the author of the Liber de Causis does, and in precisely the same context, namely, the discussion of the sifät of the First Principle, creates once again a drift towards the conclusion that he was aware of the passage quoted.

(iii) VIII 6, p. 355.9-12 (p. 412.59-64) and IV 3, p. 188.5-189.11 (p. 215.17-216.34) - In chapter 6 of treatise VIII, we are told that the necesse esse transcends even perfection: it is fawqa al-tamäm, plus quam perfectum. ${ }^{62}$ In a purely Neoplatonic vein, Ibn Sīnā indicates as the cause of this status the fact that its esse is not confined to itself but pours forth onto the derivative realities, giving them their own esse. ${ }^{63}$ Earlier in the Metaphysics of the Kitäb al- $\breve{S} i f \bar{a}$ ', he had already credited the First Principle with transcendence to perfection itself. In chapter 3 of treatise IV, dealing with the notions 'perfection', 'imperfection', 'transcendence to perfection' and 'totality', he had already quoted the tenet of those "wise men" (hukamāa') who credited the First Principle with the status of transcendence to perfection itself (fawqa al-tamām). According to those wise men, in Ibn Sinā's report, the First Principle lies not only above what is imperfect, but also above what is perfect, which, in his interpretation, is the intelligible world and Intellect. ${ }^{64}$

It is tempting to see in this allusion a quotation of proposition 21[22] of the Liber de Causis, where the First Principle is said to create in so far as it is above perfection itself - fawqa al-tamām, reproducing Proclus' $v \varepsilon \varepsilon \rho \pi \lambda \eta \rho \varepsilon \zeta^{65}$ As a matter of fact, the striking similarity between Ibn Sinnā's

60 Liber de Causis, prop.5[6], p. 70.2-7 Bardenhewer, p. 9.1-4 Badawī; transl. Taylor, The Liber de Causis (Kalām fi mahd al-hayr). A Study of Medieval Neoplatonism, p. 292.

61 The passage of the Liber de Causis is inspired by the following passage from El. th. 11, Dodds p. 12.15-17: ñ $\gamma$ ò

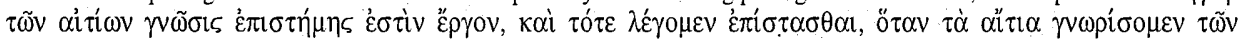
öv $\tau \omega \mathrm{v}$.

62 Arabic: p. 355.9; Latin: p. 412.59-60.

63 Arabic: p. 355.9-10; Latin: p. 412.59-61.

64 IV 3: Arabic, p. 188.5-189.11; Latin: p. 215.17-216.34: «Dico autem quod sapientes etiam transtulerunt perfectum ad certitudinem essendi (...). Plus quam perfectum autem est id cui est esse quod debet habere et ab eo exuberat esse ad ceteras res, veluti si habeat suum esse quale oportet eum habere, et habet esse superabundans quo non est ei opus, et ab eo exuberet ad alia, et hoc sit ab eo essentialiter. Et hunc ordinem attribuerunt primo principio quod est ultra perfectionem, ex cuius esse in seipso, non ex causa alia ab eo, fluit esse exuberans a suo esse ad ceteras res. Et ordinem perfectionis attribuerunt intelligentiae ei quae, ex intelligentiis separatis, in principio sui esse est in effectu, cui non commiscetur aliquid potentiae nec exspectat alius esse. Si autem fuerit aliquid aliud ab ea, hoc etiam est ab esse quod fluit a primo» (my. emphasis; see below, n. 67).

65 Liber de Causis, prop. 21[22], p. 99.9-100.1 Bardenhewer, p.23.1-2 Badawī: «He is above perfection because He is Originator of things and that which pours forth goods on them in a perfect emanation because He is a good which has neither limits nor dimensions», transl. Taylor, The Liber de Causis (Kaläm fĩ mahd al-hayrr). A Study of Medieval Neoplatonism, p. 318. This sentence comes from Proclus' prop. 131, Dodds p. 116.22-23. 
statement and the proposition 21[22] of the Liber does not count in itself as a proof of his knowledge of this text, in so far as the same doctrine and terminology is found also in the pseudoTheology, paralleling a passage of $\mathrm{V}$ 2[11] where Plotinus is speaking about the One as ט $\pi \varepsilon \rho \pi \lambda \tilde{\eta} \rho \varepsilon \varsigma^{66}$ Not only so, but one can confidently say that the source of Ibn Sinā's account of the opinion of the hukamä' about the First Principle as fawqa al-tamām is precisely the passage of the pseudo-Theology. The identity the "wise men" stated, according to Ibn Sinnā, between the "perfect" and the intelligible world - Intellect ${ }^{67}$ is explicitly uttered in the passage of the pseudo-Theology. ${ }^{68}$ This detail, which is peculiar to the pseudo-Theology in so far as it appears in a passage which has no correspondent in Greek, makes clear that the paraphrasis of V 2[11] is the source of Ibn Sinnā's statement. What is more intriguing is the fact that in the next sentence he proceeds to establish a threefold hierarchy -the principle which is perfect; the sufficiens (al-muktafi); the insufficiens (alnāqis) — which is not present as such in the passage of the pseudo-Theology, but is still attributed by Ibn Siña to the hukamā' mentioned at the beginning of this section:

wa-ğa 'alü dīna l-tamämi šay'ayni: al-muktafiya wa-l-nāqișa.

Id autem quod est infra perfectum posuerunt duo, scilicet sufficiens et insufficiens. ${ }^{69}$

True, this hierarchy can be derived, in principle, from the passage of the pseudo-Theology as well $;{ }^{70}$ but Ibn Sinā's terminology and thought is more akin to the above-mentioned proposition 21[22] of the Liber de Causis. Echoing Proclus' threefold hierarchy $v \pi \varepsilon \rho \pi \lambda \tilde{\eta} \rho \varepsilon \varsigma$ - $\pi \lambda \tilde{\eta} \rho \varepsilon \varsigma$ $\varepsilon \lambda \lambda \varepsilon i \pi{ }^{1}{ }^{71}$ the author of the Liber de Causis states that the absolute transcendence of the First Cause depends upon the fact that it is not only perfect, but above perfection. In fact, it does not simply transcend what is imperfect — diminutum, nāqiș-, but also what is perfect -completum, tämm-, and consequently it is supra completum, fawqa al-tamām. ${ }^{72}$ The reason for this has been given immediately before:

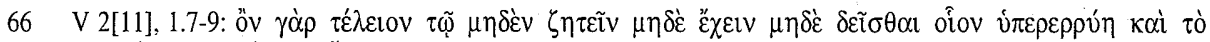

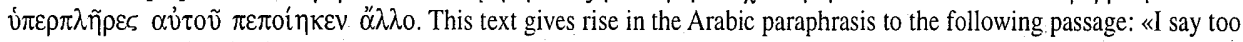
that the absolute One is above completeness and perfection (fawqa al-tamām wa-l-kamāl). The sensible world is defective (nāqis ) because it is originated from the complete thing (al-say)' al-tämm), which is mind; mind is complete and perfect because it is originated from the true absolute One, which is above completeness», Badawi, Aflit in 'inda l-'Arab, p. 134.16135.2; Lewis' translation (quoted above, n. 3), p. 291.

67 See above, n. 64. The relevant part of Ibn Sinnās statement, in the Arabic, is p. 189.1: wa-ğa'alū martabata ltāmāmi li-'aqlin mina l-'uqüli al-mufäriqati.

68 See above, n. 66. I owe to Ahmed Hasnaoui the remark that in the entire chapter Ibn Sinā does not indicate by the term hukamä' a specific "group" of thinkers, but the thinkers or authors in general, without committing himself to accept or refuse the doctrines quoted.

69 IV 3, Arabic: p. 189.4; Latin: p. 216.35-36. What follows in Ibn Sīnā’s sentence counts as an explanation of his own: «Sufficiens (al-muktafi) est id cui attributum est aliquid per quod acquisitum est ei complementum sui in seipso. Insufficiens (al-nāqis) vero absolute est id quod eget alio quod attribuat sibi completionem post completionem» (pp. 216.36-217.39; Arabic: p. 189.4-6).

70 See n. 66.

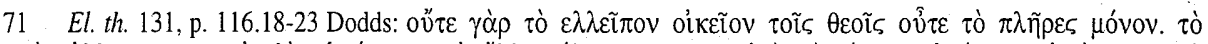

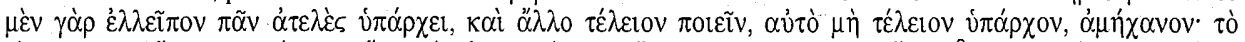

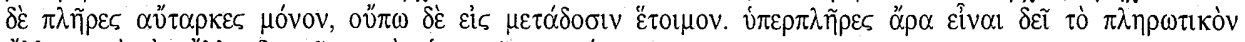

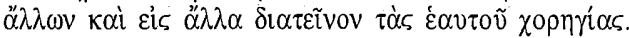

72 Liber de Causis, prop. 21[22], p. 99.8-9 Bardenhewer, p. 22.14-23.1 Badawī. 
wa-d̄âlika annahū lā yalīqu bi-hā l-nuqșānu wa-lā l-tāmāmu wahdahū li-anna l-nāqișa gayru tāmmin wa-lā yaqdaru an yaf'ala fí lan tāmman id kāna nāqișan wa-l-tämmu 'indanā wa-in kāna muktafìan bi-nafsihi fa-innahü lā yaqdaru 'alā ibdā 'i šay' in āhara wa-lā an yufịda 'an nafsihi say'an al-batta.

For neither deficiency nor mere perfection is appropriate to Him because the deficient is imperfect and unable to effect a perfect act since it is deficient. The perfect, in our view, although sufficient in itself, is unable to originate another thing and to pour forth anything from itself at all (transl. Taylor) ${ }^{73}$

This is the passage which seems to lie in the background of Ibn Sīnā's threefold hierarchy of fawqa al-tamām - namely, the necesse esse-, al-tāmm, al-muktafī - namely, Intellect and the intelligible world - and al-nāqis — which is the world of coming-to-be and passing away. Not only because of the terminology - the term muktafi appears in the De causis passage, but not in the one from the pseudo-Theology-, but also because of the emphasis put on the hierarchy of the three levels, which lacks in the passage of the pseudo-Theology and counts, on the contrary, as the very focus of the passage of the De causis. There is a shift in Ibn Sinā's terminology, because when the necesse esse is said to be fawqa al-tamām, Intellect is called al-tämm; on the other hand, when he mentions the two subordinate degrees al-muktafĩ and al-näqis, the first degree (the necesse esse) is called simply al-tämm. This means that he feels free to rework in his own way the doctrine he is gleaning from his sources. But this does not prevent this passage from counting as an interesting case in point. In fact, if the analysis I have made is correct, Ibn Sinā is echoing both the pseudoTheology' and the Liber de Causis under the common heading of the "opinion of the hukamä ". $\mathrm{He}$ deals with both the Neoplatonic texts, the pseudo-Theology and the De causis, as with one and the same source, even though he subdivision of what comes after the first into the two degrees al-muktafi and al-nāqiș does not come from the passage of the pseudo-Theology', but from the Liber de Causis. Ibn Sīnā credits also with this doctrine the hukam $\bar{a}$ ' he mentioned at the beginning of this passage.

Something similar happens also in the passage from VIII 6 I began with. After having claimed that the necesse esse is above perfection ${ }^{74}$ - a claim which in all likelihood traces back to the same source as the one of the passage from IV 3 we have just discussed, namely, the pseudo-Theology-, Ibn Sīnā says:

wa-wāğibu l-wŭ̆ūidi bi-d̄atihī hayrun mahdun, wa-l-hayru bi-l-ğumlati huwa mā yată̌awwa-

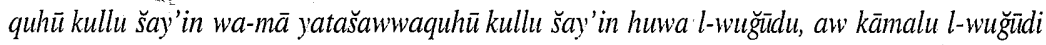
min bābi l-wuğüdi.

Necesse esse per se est bonitas pura, et bonitatem desiderat omnino quicquid est; id autem quod desiderat omnis res est esse et perfectio esse, inquantum est esse. ${ }^{75}$

73 Liber de Causis, prop. 21[22], p. 99.4-8 Bardenhewer, p. 22.14-23.1 Badawī. Transl. Taylor, The Liber de Causis (Kaläm fímahd al-hayr). A Study of Medieval Neoplatonism, p. 318. The source of this passage is Proclus' passage quoted above, n. 71 .

74. See above, n. 62.

75 VIII 6, Arabic: p. 355.11-12; Latin: p. 412.62-64. 
It is possible that this is the passage Herbert Davidson has in mind when he claims that the denomination al-hayr al-mahd (bonitas pura) for the First Principle shows that Ibn Sina is aware at least of the title of the Arabic Liber de Causis. ${ }^{76}$ But, even if one wants to leave aside the terminology, this passage contains an evident echo of proposition 22[23] of the De causis, where, in order to support the claim that the providence of the First Principle is more universal than the one of Intellect, the author argues that everything is longing for the good, which comes from the First Principle alone, whereas not everything is longing for thought, which comes from Intellect. This doctrine is directly derived from Proclus' proposition 134, which the author of the Liber de Causis is quoting almost literally. ${ }^{77}$ In particular, the passage which inspires Ibn Sinnā's statement seems to be the following:

wa-d̄alika innahū laysa kullu šay'in yaštāqu ilā l-aqli wa-lā yahrișu 'alā naylihr̃ wa-l-

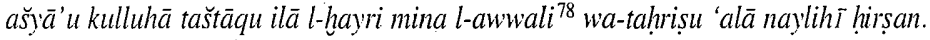

For not every thing yearns for the intelligence and is eager to attain it, but all things do yearn for the First Good and are avidly eager to attain Him (transl. Taylor). ${ }^{79}$

Once again, it seems fair to conclude that this passage lies in the background of Ibn Sīnā's statement quoted above. But if so, once again he is adding to the topic of the First Principle as fawqa al-tamām - coming in all likelihood from the pseudo-Theology - an echo from the Liber de Causis. More important, once again Ibn Sinna is conflating his two Neoplatonic sources and keeps silent about any distinction whatsoever among them, as if they were a part of one and the same corpus of doctrines inherited by the "wise men" of the past.

(iv) VIII 7, p. 365.4-7 (p. 426, 50-56) - In this passage Ibn Siñā outlines the hierarchy of the intelligibles, claiming that the first intelligible reality gushes forth from the First Principle without any intermediation, bi-là wásita, and the subsequent intelligibles proceed from the First Principle through a mediation, bi-tawassut. The secondary intelligibles result from the impression (irtisäm, impressio) in one and the same reality - which is presumably the intellectual substance of each sphere- but there is a hierarchy of causal power among them. ${ }^{80}$

76 H.A. Davidson, Alfarabi, Avicenna \& Averroes, on Intellect: their cosmologies, theories of the active intellect \& theories of human intellect, Oxford, Oxford U.P., 1992, p. 164.

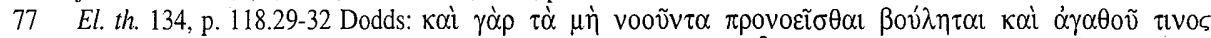

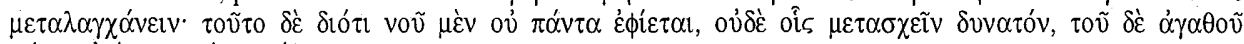

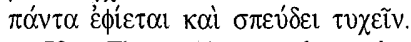

78 The words mina l-awwali which appear both in Bardenhewer and Badawi editions are an addition by Bardenhewer, maybe on the basis of the Latin translation. The correct reading, according to Taylor's edition, The Liber de Causis (Kalām fì malud al-hayr). A Study of Medieval Neoplatonism, p. 238.19, is ilä al-ḩayr al-awwal. The Latin text has «bonitatem ex primo»: see Pattin, p. 238.19 (quoted above, n. 25).

79 Liber de Causis, prop. 22[23], p. 101.7-9 Bardenhewer; p. 23.15-24.1 Badawī. Transl. Taylor, The Liber de Causis (Kalām fimahd al-hayr). A Study of Medieval Neoplatonism, p. 320. Marc Geoffroy called my attention to the $K$. al-Mabda' wa-l-ma'äd, I, 12, where Ibn Sinnā conflates the topic of the universal desire of good, coming from this passage of the De causis (if my analysis is correct) and the topic of the first principle as the final cause of the whole universe, coming from Book Lambda of the Metaphysics. I would like to thank very much Marc Geoffroy for having allowed me to read his unpublished French translation of this part of the K. al-Mabda'wa-l-ma'äd: Avicenne. Le principe et le retour, trad. et commentaire par M. Geoffroy, forthcoming.

80 VIII 7, Arabic: p. 365.4-7; Latin: p. 426, 50-56: «De universitate igitur intellectorum quiddam est intellectum ( $\left.m a^{\prime} q \bar{u} l\right)$ cuius primus est principium nullo mediante ( $b i-l a ̄$ wásịta), sed fluit esse eius ab eo principaliter, et quiddam est intellectum, cuius primus est principium aliquo mediante (bi-tawassut ), et esse fluit ab eo secundario, et similiter est dispositio de esse illorum intellectorum; quamvis enim eorum impressio sit in una re eorum, tamen quaedam sunt prius et posterius secundum ordinem causae et causati». 
The derivation of Intellect from the First Principle bi-lā tawassut and of everything else through the mediation of Intellect is a typical doctrine of the Arabic Plotinus, which was endorsed, in turn, by the author of the Liber de Causis. ${ }^{81}$ Ibn Sinna is clearly aware of this typical feature of the Arabic Plotinus, even though he transforms it and puts it in the service of his own reasoning about the status of the intelligibles within the divine mind: he is in fact dealing here with the intellecta as they are first in essentia primi and secondarily in the subsequent separate principles. No doubt that the distinction between the immediate and mediate derivation from the essentia primi (bi-lä wásita - bi-tawassut) comes from the Arabic Plotinus. As a matter of fact, the topic of the creation of Intellect bi-lä tawassut and of everything else bi-tawassut al-'aql counts as an interpretation of a doctrine which is at one and the same time crucial for Plotinus, and aban-

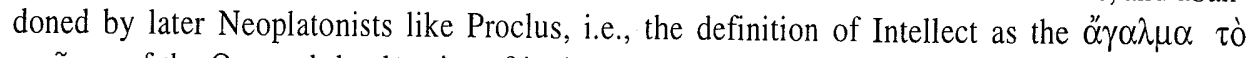
$\pi \rho \tilde{\tau} \tau 0 v$ of the One and the doctrine of its immediate derivation from the One itself. The Arabic translation-paraphrase constantly interprets this relationship as the divine creation of Intellect without any intermediate, and creation of everything else through the mediation of Intellect. This recurrent topos of the Arabic Plotinus lies in the background of Ibn Sinā's development. However, he combines the doctrine of the Arabic Plotinus with the idea of a hierarchy of intelligibles, some of which are prior to others and more powerful than others, depending upon their immediate or mediate derivation from the First Principle. This topic does not come from the Arabic Plotinus, in so far as it traces back ultimately to the Proclean doctrine of the different rank of the intelligible forms according to the hierarchical degree of the divine intellects they are intelligized by. To be more precise, Ibn Sīnā's claim recalls the doctrine of propositions 4 and $4[5]$ of the the Liber de Causis.

After having endorsed — not without modifying it - Proclus' thesis of the primacy of being among the suprasensible principles (El. th. 138), the author of the Liber parts company with Proclus and makes Intellect to be the first and immediate product of the First Cause: ${ }^{82}$ a nonProclean move indeed, which is inspired in all likelihood by the Arabic Plotinus. At this point, he comes back to the Elements of theology, but not to prop. 138, and no longer in terms of literal quotation. He takes in fact his inspiration either in prop. 177 (more likely) or in prop. 170, or again in prop. 180 - the three main places where Proclus compares the status of $\varepsilon^{\prime \prime} \delta \eta$ when considered in the superior and inferior intellects - and maintains that in the first created Intellect the intelligible forms are wider and more universal, whereas in the intellects of lower degree they are less universal..$^{83}$ As a consequence of this difference in universality, the higher intellects produce stable and subsistent forms, whereas the inferior intellects produce declining

81 For the passages proving the dependence of the Liber de Causis upon the Arabic Plotinus on this issue, see my «La doctrine de la création 'mediante intelligentia' dans le Liber de Causis et dans ses sources», in Revue des Sciences Philosophiques et Théologiques, 76 (1992), p. 209-233.

82 Liber de Causis, prop.4, p. 66.1-2 Bardenhewer, p. 6.14-15 Badawi: «Quod est quia omne quod ex eo sequitur causam primam est achili id est intelligentia completa et ultima in potentia et reliquis bonitatibus », Pattin, p. 143.54-57.

83 Liber de Causis, prop.4, p. 66.2-5 Bardenhewer, pp. 6.15-7.1 Badawī: «Et formae intellectibiles in ipso sunt latiores et vehementius universales. Et quod ex eo est inferius est intelligentia iterum, verumtamen est sub illa intelligentia in complemento et virtute et bonitatibus. Et non sunt formae intellectibiles in illa ita dilatatae sicut est earum latitudo in illa intelligentia», Pattin, p. 143.58-64. 
forms, like souls: in fact, soul comes out ex impressione intelligentiae secundae quae sequitur esse creatum inferius. ${ }^{84}$

When he claims that among the intelligibles some derive from the First Principle without any intermediation and some through a mediation, and that their "impression" in the intellectual substance which receives them creates a hierarchy (quaedam sunt prius et posterius secundum ordinem causae et causati), Ibn Sīna seems to be aware of both his Neoplatonic sources: the Arabic Plotinus as for the topic of immediacy-mediation with respect to the First Principle, and the Liber de Causis as for the one of the hierarchy among intelligibles. Once again, Ibn Sinā's use of his sources is remarkably free both from the viewpoint of doctrine and lexic. From the viewpoint of doctrine, both the topic of derivation bi-là tawassut - bi-tawassut al- 'aql and of the hierarchy among intelligibles are reworked according to his own ideas and needs. From the viewpoint of terminology, he endorses the idea of "impression", not the term itself (irtisām in Ibn Sīnā' passage, atar in the Liber de Causis).

Dimitri Gutas called attention to the fact that Ibn Sīnā «was born and raised in the Eastern parts of the Islamic Empire where Kindī's tradition was most flourishing (...); he pursued his "graduate" studies in the very library in which "Āmin most likely composed and probably deposited his On the Afterlife». ${ }^{85}$ The latter treatise is precisely the work in which the earliest quotations from the Liber de Causis are found. ${ }^{86}$ The passages analysed create a drift towards the conclusion that Ibn Sīnā was acquainted with the Liber de Causis, a text which was by no means ignored in his cultural context.

Cristina D'Ancona Costa

Viale Mameli, 37

57126 LIVORNO

ITALIA

84 Liber de Causis, prop.4[5], p. 67.4-7 Bardenhewer, p. 7.9-11 Badawī: «Intelligentiae superiores primae, quae sequuntur causam primam, imprimunt formas secundas stantes, quae non destruuntur ita ut sit necessarium iterare eas vice alia. Intelligentiae autem secundae imprimunt formas declines, separabiles, sicut est anima». As stated by Taylor, The Liber de Causis (Kalām fi mahd al-hayr). A Study of Medieval Neoplatonism, p. 156, the word «secundas», Pattin, p. 145.87, is a misreading whose Arabic antecedent al-tănña was probably in the Arabic model of the Latin translator, instead of the correct al $\underline{-t a} b i t a$, which is in the Arabic both of Bardenhewer and Badawi editions.

85 Gutas, Aricenna and the Aristotelian Tradition (quoted above, n. 14), p. 250.

86 See above, n. 22. 